\title{
Knowledge, attitude and practice of travel medicine among primary care physicians in Oman: the need for intervention
}

Padmamohan J. Kurup, ${ }^{1}$ Seif S. Al Abri, ${ }^{2}$ Fatma Al Ajmi, ${ }^{1}$ Huda A. Khamis ${ }^{1}$ and Jeffrey Singh ${ }^{1}$

${ }^{1}$ Directorate General of Health Services, Muscat, Oman. ${ }^{2}$ Disease Surveillance \& Control, Ministry of Health, Muscat, Oman. (Correspondence to: Seif S. Al Abri: salabri@gmail.com).

\begin{abstract}
Background: Oman is witnessing an increase in outbound and inbound travelers.

Aims: This study was undertaken to assess the current knowledge, attitude, and practice of travel medicine among primary care physicians (PCPs) working in the Muscat Governorate.

Methods: We conducted a cross-sectional survey of 108 primary healthcare physicians in primary healthcare institutions in the Muscat Governorate in December 2014 using a self-administered questionnaire.

Results: We had a response rate of $81 \%, 78 \%(n=84)$ were females, $56.5 \%(n=61)$ were Omani nationals. More than $50 \%(n=$ 54) of study participants had been in practice for more than 8 years. Sixty-eight (58.3\%) reported having pre-travel consultations during the previous 1-month period and 86 (79.6\%) had post-travel consultations. Most of the PCPs were aware of the issues that needed to be addressed in pre-travel consultation.

Conclusions: This study showed that travel health is in an early stage of development in Oman and supports the need for the establishment of travel medicine services.

Keywords: travel, Oman, knowledge, vaccination, prophylaxis, primary healthcare

Citation: Kurup PJ; Al Abri SS; Al Ajmi F; Khamis HA; Singh J. Knowledge, attitude and practice of travel medicine among primary care physicians in Oman: the need for intervention. East Mediterr Health J. 2019;25(1):40-46. https://doi.org/10.26719/emhj.18.027

Received: 02/08/15; accepted: 05/09/17

Copyright (C) World Health Organization (WHO) 2019. Some rights reserved. This work is available under the CC BY-NC-SA 3.0 IGO license (https://creativecommons.org/licenses/by-nc-sa/3.o/igo).
\end{abstract}

\section{Introduction}

Internationally, travel has become a very common practice whether for business, pleasure or other reasons. The number of international travelers is estimated at 900 million per year and is projected to reach 1.6 billion per year in 2020 (1). Oman is witnessing a significant increase in outbound as well as inbound travelers and this is likely to increase exponentially with the introduction of enhanced airport facilities in the country. This, combined with a large expatriate population that frequently travels to home countries, makes travel-related diseases an important public health issue (2). It also sets the need for a travel medicine service to cover travel-related diseases and other health issues such as the risks associated with long-haul flights.

Oman is located in the south-eastern part of the Arabian Peninsula with a land area of 309500 square kilometres, and the country is divided into 11 administrative governorates. The mid-year population in 2014 was 3.9 million, of which $43 \%$ are expatriates. Most of the population is located in the north and south of the country. Oman has achieved remarkable developments in healthcare within a relatively short span of four decades and has implemented good infrastructure for health services. Healthcare in Oman is largely the responsibility of the state and the cost is borne by the government. As of 2013, the Ministry of Health $(\mathrm{MOH})$ had 195 primary care centres and 49 hospitals. Out of these 49 hospitals, four are in the capital Muscat, which offers tertiary care services. The primary health centres offer primary care services to the population residing in the assigned catchment area of the centre. The secondary and tertiary care services are provided through a referral process (3). Services are free for Omani nationals; however, the expatriate workforce access to free medical care is limited to emergency services only (2).

Travel medicine is an emerging discipline born from the rising demand of the traveling population. However, practicing physicians have not given the importance that is due for travel-related risks and issues (4). The practice of travel medicine is complex; there are currently dynamic changes in global health risks and with increasing population mobility, emerging diseases, lifestyle diseases, and various other host factors, all of which result in the complexity of travel medicine. In addition, travelers include at-risk groups: pregnant women, the very old and the very young (4-7). To add to the complexity of the practice of travel medicine, there is an expansion in new vaccines targeted at travelers. Travel medicine clinics can advise on the required and recommended health precautions needed before traveling through an individual risk assessment as well as offering services for returning travelers.

Primary care physicians (PCPs) are often the first line contacts for travelers seeking pre-travel advice or posttravel consultation, and their role has become increasingly significant. Physicians advising travelers need to know about the changing epidemiology of travel-associated 
diseases and the availability of specific new preventive and treatment measures $(8,9)$. Several worldwide surveys have investigated the quality of travel medicine practice among PCPs since 1987 (1,9-16). There are significant differences among PCPs in the quality of advice given and also in their efforts to improve the quality of PCP practices in this field $(10,12,16)$. In addition, the high level of knowledge in travel medicine was mostly linked to PCP motivation to practice in this specialized field (1).

A retrospective analysis of communicable diseases notified between 1999 and 2013 in Oman showed that travel-associated infections account for $8 \%$ of reported cases. Typhoid, measles, and dengue fever were the most common infections reported (17). Malaria cases are notified through a separate vertical programme. As per annual statistical reports from the $\mathrm{MoH}$, the incidence of malaria is showing an increasing trend from a low of 443 in 2006 to 2051 in 2012 and the occurrence is predominantly in foreign nationals (3). In Oman, individuals who travel abroad, especially to endemic African countries, can get malaria prophylaxis from primary care centres. In addition, people going on pilgrimage to Saudi Arabia and those traveling to countries affected by yellow fever (YF) receive the mandatory meningococcal vaccine and YF vaccine, respectively, from primary health care centres. However, there is a lack of information about the extent of use of travel-related medical consultations in the primary care setting in Oman, although there are data available on the type and extent of advice and prophylactic treatment provided. The KAP study of Muscat International Airport travelers from Oman reported that even though more than $50 \%$ of respondents had a positive attitude towards travel medicine, only $22.5 \%$ sought advice and only $6.9 \%$ reported seeking pre-travel advice. The study reports inadequate levels of traveler knowledge and poor utilization of travel medicine services and recommends the development of a well-structured travel medicine service and promotional strategy (18).

The aim of this study was to assess the current knowledge, attitude, and practice of travel medicine of PCPs in the Muscat Governorate with a special interest on health advice, vaccinations, and malaria prophylaxis. In addition, we aimed to identify the factors associated with a higher level of specific knowledge of travel medicine.

\section{Methods}

We conducted a cross-sectional survey of PCPs in primary health care institutions in the Muscat Governorate during the month of December 2014. There were 361 PCPs distributed among 28 primary care institutions in the Muscat Governorate. They cater primarily to the Omani population but also offer travel-related vaccinations and malaria chemoprophylaxis to non-Omanis. We expected to recruit 100 participants and assumed that $50 \%$ of PCPs would have adequate awareness levels with regard to travel medicine relevant for the country. The sample size calculated for $+/-10 \%$ precision. A self-administered questionnaire was distributed to all PCPs who were working in 14 randomly selected primary care centres represent- ing all locations of the Muscat Governorate. There are a total of 28 primary care centres in the Muscat Governorate each having around 10 to 14 PCPs. The questionnaire was prepared in English specifically for the study and was pilot tested. It was developed focusing on the same domains that were used in similar published literature $(9,16)$. Although assessment of attitudes were included, no attempt was made to establish validity of questionnaire as the study primarily focused on current knowledge and practice relevant to the Omani setting. Ethical approval was obtained from the research committee at the Directorate General for Health Services for the Muscat Governorate.

The questionnaire covered demographic information, the setting of the general practice, and travel healthrelated knowledge and practice. We assessed the extent of pre-travel consultations in the practice and the travel health-related issues addressed in such consultations. Respondents were asked about specific travel health issues related to YF, malaria chemoprophylaxis, travelers' diarrhoea, and air travel-related health problems. Some questions were designed to understand the nature of the resources available for general practitioners (GPs) with respect to travel health, any training undertaken, and their attitude to travel medicine practice.

Data collected were entered in EpiData software (version 3.1) and analysed using SPSS (version 16.0). We used proportions to describe the information. The association between knowledge scores and PCP characteristics were analysed using chi square statistics. The knowledge levels were analysed by assigning scores for each correct response and a total score was calculated (maximum score $=14$ ). The knowledge score was analysed as a dichotomous variable taking mean (which also corresponded to 50\% score) as cut off. Crude and adjusted odds ratios with $95 \%$ confidence limits were calculated for those variables that were considered relevant for the study. All tests were considered significant if $\mathrm{P}<0.05$.

\section{Results}

The questionnaire was distributed to 134 PCPs and 108 participated, a response rate of $81 \%$. Among the 108 respondents, 84 (78\%) were female, 61 (56.5\%) were Omani nationals, while the rest were various other nationalities. Forty-three $(40 \%)$ of the respondents graduated from medical schools in Oman. Fifty-four (50\%) of the study participants had been in practice for more than eight years. Thirty-four $(32 \%)$ had postgraduate qualifications. These characteristics are summarized in Table 1.

\section{Extent of travel medicine practice}

Most practitioners see an average of 30 patients per day; $68(58.3 \%)$ report having carried out pre-travel consultations during the previous 1-month recall period (Figure 1). Seventy-five percent of PCPs see less than five consultations per month with median number of three consultations [interquartile range (IQR) 2-6]. Eighty-six (79.6\%) reported that they have provided post-travel consultations. Fever, diarrhoea, skin disorders, and respiratory infections were the top four presentations during post-trav- 


\begin{tabular}{|c|c|}
\hline Characteristics of study participants & \# (\%) \\
\hline Gender $(n=108)$ & \\
\hline Male & $24(22 \%)$ \\
\hline Female & $84(78 \%)$ \\
\hline Nationality $(n=108)$ & \\
\hline Omani & $61(57 \%)$ \\
\hline Non-Omanit & $47(43 \%)$ \\
\hline Graduation $(n=108)$ & \\
\hline In Oman & $43(40 \%)$ \\
\hline Outside Oman & $65(60 \%)$ \\
\hline Postgraduate training $(n=108)$ & \\
\hline Yes & $34(32 \%)$ \\
\hline No & $74(68 \%)$ \\
\hline Clinical experience ( $\mathrm{n}=99)$ & \\
\hline Less or equal to 3 years & 14 \\
\hline 4 to 8 years & 31 \\
\hline 9 to 15 years & 27 \\
\hline 16 years or more & 27 \\
\hline Practice levels (consultations/day) $(n=98)$ & \\
\hline Up to 20 consultations & $23(23.6 \%)$ \\
\hline 21 to 30 consultations & $41(41.8 \%)$ \\
\hline 31 to 40 consultations & $25(25.5 \%)$ \\
\hline 41 to 50 consultations & $9(9.1 \%)$ \\
\hline Pre-travel consultations in the past month ( $n=$ & \\
\hline Yes & $63(58 \%)$ \\
\hline No & $45(42 \%)$ \\
\hline Post-travel consultation in the past year $(n=10$ & \\
\hline Yes & $86(80 \%)$ \\
\hline No & $22(20 \%)$ \\
\hline Access to journals in primary care setting $(n=10$ & \\
\hline Yes & $36(33 \%)$ \\
\hline No & $72(67 \%)$ \\
\hline Source of information $(n=108)$ & \\
\hline Reviews & $53(49 \%)$ \\
\hline MoH guidelines & $26(24 \%)$ \\
\hline Expert/senior staff & $11(10 \%)$ \\
\hline Websites & $8(7 \%)$ \\
\hline Others (books, journals, CDs) & $10(10 \%)$ \\
\hline Attended travel medicine updates (CME) $(n=10$ & \\
\hline Yes & $19(18 \%)$ \\
\hline No & $89(82 \%)$ \\
\hline Most common presentations (post travel, $n=86$ & \\
\hline Fever & $72(84 \%)$ \\
\hline Diarrhoea & $66(77 \%)$ \\
\hline Skin problems & $41(48 \%)$ \\
\hline Respiratory infections & $36(42 \%)$ \\
\hline Trauma & $29(34 \%)$ \\
\hline Other problems & $27(31 \%)$ \\
\hline Other infections & $26(30 \%)$ \\
\hline Knowledge levels (No. of correct responses, $n=1$ & \\
\hline Yellow fever vaccination & $64(59 \%)$ \\
\hline Malaria chemoprophylaxis & $51(47 \%)$ \\
\hline Travelers' diarrhoea & $55(51 \%)$ \\
\hline Case practice: diarrhea in returned traveler & $11(10 \%)$ \\
\hline Long haul flight risks & $82(76 \%)$ \\
\hline Air travel risks & $31(29 \%)$ \\
\hline
\end{tabular}

el consultations (Table 1). Fifty-five (50\%) respondents reported that they referred to journals rarely during a 6 -month recall period. For specific travel medicine-related information, reviews were the common source for information for most practitioners; 26 (24\%) informed that they depended on $\mathrm{MoH}$ circulars, and $11(10 \%)$ on expert opinion. Nineteen $(18 \%)$ had attended the short introductory update for travel medicine conducted by the Governorate in October 2014 (Table 1).

\section{Knowledge Scores}

The extent of correct responses obtained for questions that were aimed at assessing knowledge is provided in Table 1. A scoring criterion was applied with 14 as the maximum score. The mean score obtained was 7.1 (SD 2.7, Median 8, IQR 5-9). We explored the association of certain PCP characteristics such as postgraduate training, clinical experience, pre-travel consultation experience, post-travel consultation experience, attendance to travel medicine continuing medical education programmes (CME) and the extent of journal use with knowledge scores (Table 2).

\section{Attitudes}

The perceptions and practice of the PCPs with respect to issues relating to travel health practice in their primary healthcare setting was explored; $72 / 97$ respondents (74\%) strongly agreed for the need to have training in travel health, and even with the understanding it would not be free, 55/95 (58\%) expressed interest to attend a locally available course. For updates regarding general practice seventy-eight $(80 \%)$ out of 97 of the respondents referred to scientific journals or expert opinion and only 43/97 (45\%) consulted $\mathrm{MOH}$ circulars and guidelines.

\section{Discussion}

Fifty-eight percent of the PCPs who participated in the study reported pre-travel-related consultations in their practice. Al Hajri M et al. reported that $44.7 \%$ of participating primary healthcare physicians provided pre-travel medical advice in Qatar (9). Reports from developed countries show a much higher proportion, such as 90\% of GPs in Germany and $85 \%$ in the UK $(12,19)$. Travel medicine-related consultations in Oman, though to a lesser extent, are confined to physicians alone whereas in some countries, such as the United Kingdom, nurses play an active role. The low consultation rate in our study could be due to the lack of designated travel medicine clinics as well as poor awareness among the public. Perceived risk by a traveler is an important determinant for seeking travel medicine services. Poor risk perception leads to less seeking of pre- and post-travel medicine services. A study looking at travel health KAP of travelers in Oman showed that even among experienced travelers, the overall level of knowledge about vaccine-preventable diseases, food safety, and preventive measures against insect bites was inadequate. About one fifth of travelers in this study had poor knowledge scores regarding the risk of travel-associated illnesses and their prevention. Moreover, $75 \%$ of travelers with a negative attitude towards travel medicine denied the need for any preventive measures (18). However, with the increasing need to cater to the mandatory travel health requirements for Hajj or travel to certain African countries, such consultations are increasing and this might have created the need to incorporate these 


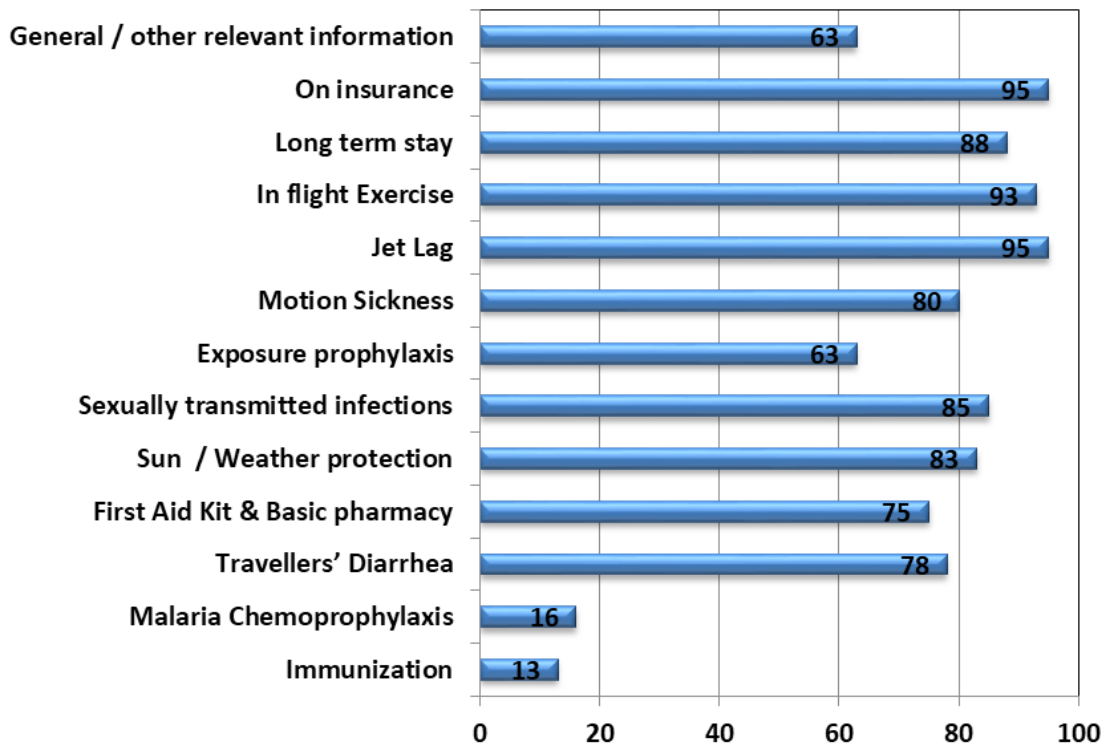

Figure 1 Percentage of respondents addressing specific pre-travel consultation issues (a total of 63 respondents had pre-travel consultations; however, $n$ varies from 58 to 63 )

services in primary health care.

Most of the PCPs in our study were aware of the issues that need to be addressed in pre-travel consultation, and in most consultations these issues were addressed. However, immunizations and malaria chemoprophylaxis were found to be addressed in lower rates than expected. This finding could be due to the fact that PCPs relate vaccinations to YF, which is not available in all institutions. It is also important to note that Oman has a historical connection with Zanzibar and travel to East Africa by a major segment of the Omani population is very frequent, which could result in less importance given to pre-travel consultation for travel to this part of Africa. Other studies, such as the one by Piotte et al., have highlighted that "quality of advice given differs substantially from one PCP to another" and our findings indicate the same (1). The study from Qatar also reported that "GPs generally gave advice to travelers regarding travel vaccines, malaria prophylaxis, STI, personal protective measures against insect bites, first aid knowledge and safety" (9). The findings from our study suggests the need for improving the quality of pre-travel health care provisions especially pre-travel vaccinations, malaria prophylaxis, and prevention.

Post-travel consultations were reported in the practice of 86 (80\%) PCPs. In Oman anti-malarials are

\begin{tabular}{|c|c|c|c|c|c|}
\hline PCP characteristics & Category & Score $</=7$ & Score $>7$ & $\begin{array}{l}\text { Odds ratio (95\% } \\
\text { C.I) }\end{array}$ & $\begin{array}{l}\text { Adjusted Odds } \\
\text { ratio (95\% C.I) }\end{array}$ \\
\hline \multirow[t]{2}{*}{ Postgraduate } & No & $33(69 \%)$ & $39(67 \%)$ & \multirow[t]{2}{*}{$0.93(0.41-2.12)$} & \multirow[t]{2}{*}{$0.85(0.26-2.75)$} \\
\hline & Yes & $15(31 \%)$ & $19(33 \%)$ & & \\
\hline \multirow[t]{2}{*}{ Clinical experience } & $<9$ years & $20(46 \%)$ & $26(47 \%)$ & \multirow[t]{2}{*}{$0.93(0.42-2.06)$} & \multirow[t]{2}{*}{$0.79(0.26-2.41)$} \\
\hline & 9 years & $24(54 \%)$ & $29(53 \%)$ & & \\
\hline \multirow{2}{*}{$\begin{array}{l}\text { Pre-travel consultation } \\
\text { experience }\end{array}$} & No & $19(40 \%)$ & $24(41 \%)$ & \multirow[t]{2}{*}{$1.08(0.49-2.35)$} & \multirow[t]{2}{*}{$0.68(0.23-2.01)$} \\
\hline & Yes & $29(60 \%)$ & $34(59 \%)$ & & \\
\hline \multirow{2}{*}{$\begin{array}{l}\text { Post-travel consultation } \\
\text { experience }\end{array}$} & No & $13(27 \%)$ & $9(16 \%)$ & \multirow[t]{2}{*}{$2.02(0.78-5.26)$} & \multirow[t]{2}{*}{$1.89(0.5-7.17)$} \\
\hline & Yes & $35(73 \%)$ & $49(84 \%)$ & & \\
\hline \multirow{2}{*}{$\begin{array}{l}\text { Participation in travel } \\
\text { medicine CME }\end{array}$} & No & $38(80 \%)$ & $49(84 \%)$ & \multirow[t]{2}{*}{$1.43(0.5-3.9)$} & \multirow[t]{2}{*}{$2.23(0.64-7.65)$} \\
\hline & Yes & $10(20 \%)$ & $9(16 \%)$ & & \\
\hline \multirow[t]{3}{*}{ Journal use } & Nil/Rarely & $16(53 \%)$ & $17(50 \%)$ & \multirow[t]{3}{*}{$0.79(0.37-1.67)$} & \multirow[t]{3}{*}{0.66 (0.29-1.49) } \\
\hline & Occasional & $9(30 \%)$ & $16(47 \%)$ & & \\
\hline & Frequent & $5(17 \%)$ & $1(3 \%)$ & & \\
\hline
\end{tabular}


available only in $\mathrm{MoH}$ institutions and malaria cases in Oman are all imported. This would possibly contribute to higher post-travel consultations in the primary care setting. Fever and diarrhoea were the most common presentations following travel. Typhoid, measles and dengue fever were the most common travel-associated infections reported through communicable disease surveillance in Oman (17). The majority of travelassociated infections were reported among expatriate males from South Asia aged between 19 and 35 (17). This group has limited access to free medical services. Travelassociated infections in Oman, although they have a low mortality rate, are considered to be a threat to sensitive polio eradication and measles elimination programmes. In the case of malaria, imported Plasmodium vivax cases are diagnosed most often in expatriate workers from the Indian subcontinent. Plasmodium falciparum cases arise in Omani nationals traveling to East Africa $(2,3)$. The importance of travel-related illnesses, especially infections, is emphasized as part of disease surveillance in the primary care setting in Oman. This would also contribute to a better awareness of the importance of post-travel consultations among PCPs.

The wide range of sources relied on by the study participants for travel medicine-related information indicates the need for a uniform standard guidance system in this area. Several studies showed the availability of country-specific methods adopted by practitioners to access information; for example, the Internet in Qatar (78.9\%), online access to a medical library in the United Kingdom, and a national handbook in Germany $(9,12,19)$. Leggat et al. reports that $96 \%$ of GPs surveyed in New Zealand found that "the most useful resource was Health Advice for Overseas Travellers, which outlines the New Zealand recommendations for medical practitioners providing travel health advice" (20).

Our study demonstrated substantial differences in knowledge levels in each specific area assessed (Table 1). We attempted to explore associations of adequate knowledge scores with qualification, experience, training, etc. (Table 2). Attending travel medicine CME and experience of post-travel consultations in their clinical practice increased the probability of a higher knowledge score in the study. However, none of these associations were found to be statistically significant, possibly due to our small sample size, which was not calculated to test an association. However, the findings do suggest that exposure to travel-related illnesses, pretravel consultations, and regular targeted educational programs would help significantly in establishing travel medicine services with substantial quality.

More than $80 \%$ of respondents expressed a positive attitude and eagerness to undertake travel medicine training. This positive attitude among the PCPs will be an asset in the development of services in primary health care system. A significantly higher proportion of respondents referred to scientific journals or expert opinion when in doubt, compared to $45 \%$ who referenced $\mathrm{MoH}$ guidelines or circulars. PCPs need an understanding of global health issues, emerging illnesses and health risks, vaccines, antimalarial drugs, drug resistant organisms, and familiarity with changing health regulations in order to provide an effective pre-travel advice $(2,7,9)$. The specific knowledge and practice deficits brought out indicate that there is a need for establishing practice guidelines, and educational programs for PCPs.

The experience of different approaches utilized in different parts of the world, such as CME accreditation in the United States of America, networking in the United Kingdom (National Travel Health Network and Centre - NaTHNaC), or the travel health practitioner's registry system in the Netherlands could be explored to develop an appropriate strategy for Oman $(16,21,22)$. The development of a "ready to use" handbook in the context of Oman would be an area to focus on in the current situation in addition to online access to health information in the clinics. These findings also indicate the need for organizing the services with high-quality training and support materials, and for continuous educational and professional development.

Our study found that most of the PCPs surveyed did not have any formal training in travel medicine. However, a majority of them indicated the need for training, especially in the form of short courses with certification. It is important that undergraduate and postgraduate medical curricula to include more training in travel medicine $(23,24)$.

\section{Limitations}

Our study was not without its limitations. It was confined to $\mathrm{MoH}$ institutions which are not consulted often by non-Omanis. Although pre-travel immunizations and malaria chemoprophylaxis is available only through $\mathrm{MOH}$ institutions, it is likely that travel-related consultation patterns of expatriates are not reflected accurately in the study. It is also important to note that some of the responses needed recall, which could have led to bias. The study was attempted using a questionnaire developed for the setting of Oman adapted from main areas focused upon in similar published studies and was not subjected to strict validation process. This may have led to major bias in the findings relating to attitudes of the respondents. The study sample was not adequate to identify factors associated with poor knowledge levels, hence caution needs to be exercised in interpreting this finding.

\section{Conclusion}

This study showed that travel health as a discipline is in its early stages of development in Oman and supports the need for establishment of travel medicine services. The service provision was not distributed evenly in terms of quantity or quality. In order to set the programme in its right direction, the information obtained from this study becomes significant. The results of the study provided information on the status of travel medicine services delivered through the primary care setting in the Muscat Governorate, which can be considered as a snapshot of the available service in the country. 


\section{Acknowledgments}

Authors wish to thank all participants whose cooperation made the completion of this study possible.

Funding: None.

Competing interests: None declared.

\section{Connaissances, attitudes et pratiques concernant la médecine des voyages chez les médecins de soins de santé primaires à Oman : besoin d'intervention}

\section{Résumé}

Contexte : Oman est confronté à une augmentation du nombre de voyageurs qui entrent dans le pays ou qui en sortent.

Objectifs : La présente étude a été réalisée pour évaluer les connaissances, les attitudes, les pratiques courantes en matière de médecine des voyages parmi les médecins de soins de santé primaires travaillant dans le gouvernorat de Mascate.

Méthodes: Nous avons mené une enquête transversale auprès de 108 médecins de soins de santé primaires dans des établissements de ce niveau de soins dans le gouvernorat de Mascate en décembre 2014 à l'aide d'un auto-questionnaire.

Résultats: Nous avons eu un taux de réponse de $81 \% ; 78 \%(\mathrm{n}=84)$ étaient des femmes, $56 \%(\mathrm{n}=61)$ étaient des ressortissants omanais. Plus de $50 \%(n=54)$ des participants de l'étude exerçaient depuis plus de huit ans. Soixantehuit médecins $(68,3 \%)$ signalaient avoir eu des consultations préalables au voyage durant le mois qui précédait et 86 médecins $(79,6 \%)$ avoir eu des consultations au retour du voyage. La plupart des médecins de soins de santé primaires connaissaient les points à aborder lors des consultations préalables au voyage.

Conclusions : Cette étude a montré que la médecine des voyages est à un stade de développement précoce à Oman et vient étayer la nécessité de mise en place de services pour ce type de médecine.

$$
\begin{aligned}
& \text { معلو مات واتجاهات وممارسات أطباء الرعاية الأولية بخصوص طب السفر في عُمان: الحاجة إلى التدخل } \\
& \text { بادماموهان كوروب، سيف سالم العبري، فاطمة العجمي، هدى خميس، جيفري سميث } \\
& \text { الخلاصة } \\
& \text { الخلفية: تشهد عُعان زيادة في عدد السكان المسافرين منها وإليها. }
\end{aligned}
$$

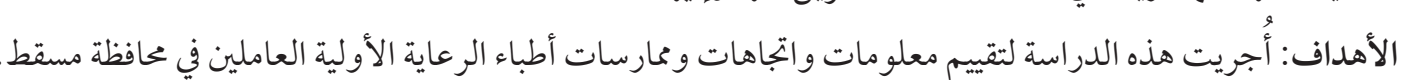

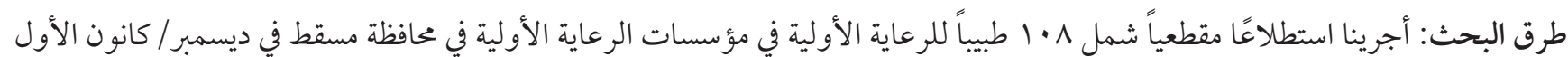

$$
\begin{aligned}
& \text { ع ا ب ب باستخدام استبيان ذاتي الإجابة. }
\end{aligned}
$$

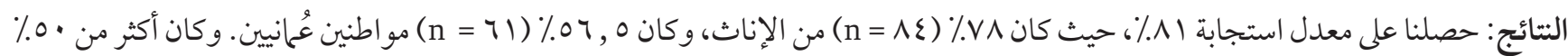

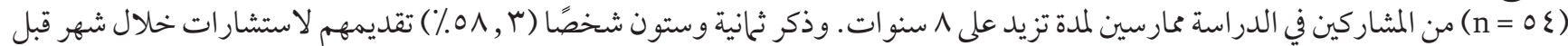

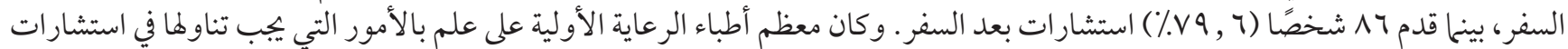

$$
\begin{aligned}
& \text { قبل السفر. } \\
& \text { الاستنتاجات: توضح هذه الدراسة أن الصحة أثناء السفر لا تزال في مرحلة مبكرة من التطور في عُمان، وتدعم الحاجة إلى إنشاء خدمات طب السفر. }
\end{aligned}
$$

\section{References}

1. Piotte E, Bellanger AP, Piton G, Millon L, Marguet P. Pre-travel consultation: evaluation of primary care physician practice in the Franche-Comté region. J Travel Med. 2013;20(4):221-7. http://dx.doi.org/10.1111/jtm.12030

2. Schlagenhauf PJ, Jones ME. Travel medicine in Oman - Chances and challenges. Travel Med Infect Dis. 2015 Sep-Oct;13(5):351-2. http://dx.doi.org/10.1016/j.tmaid.2015.09.009

3. Ministry of Health, Sultanate of Oman. Annual Health Report, 2013, Directorate General of Planning, Ministry of Health. Chapters $1-3$

4. Price VA, Smith RA, Douthwaite S, et al. General physicians do not take adequate travel histories. J Travel Med 2011; 18:271-4. doi: 10.1111/j.1708-8305.2011.00521. x. Epub 2011 Jun 15.

5. Bruni M, Steffen R. Impact of travel-related health impairments. J Travel Med. 1997;4(2):61-4. http://dx.doi. org/10.1111/j.1708-8305.1997.tboo781.x 
6. Hill DR. Health problems in a large cohort of Americans traveling to developing countries. J Travel Med. 2000;7(5):259-66. http:// dx.doi.org/10.2310/7060.2000.00075

7. Reid D, Keystone J, Cossar J. Health risks abroad, general considerations. In: DuPont H, Steffen R, editors. Textbook of travel medicine and health. 2nd ed. Hamilton: BC Decker; 2001. pp. 3-10.

8. Ingram RJH, Ellis-Pegler RB. What's new in travel medicine? NZ Public Health Rep. 1996;3:57-9.

9. Al-Hajri M, Bener A, Balbaid O, Eljack E. Knowledge and practice of travel medicine among primary health care physicians in Qatar. Southeast Asian J Trop Med Public Health. 2011;42:1546-52.

10. Usherwood V, Usherwood TP. Survey of general practitioners' advice for travellers to Turkey. J R Coll Gen Pract. 1989;39:148-50.

11. Leggat P. Sources of health advice given to travelers. J Travel Med. 2000;7(2):85-8. http://dx.doi.org/10.2310/7060.2000.00027

12. Ropers G, Krause G, Tiemann F, Beest Holle M, Stark K. Nationwide survey of the role of travel medicine in primary care in Germany. J Travel Med. 2004;11(5):287-94. http://dx.doi.org/10.2310/7060.2004.19104

13. Thava Seelan S, Leggat PA. Health advice given by general practitioners for travellers from Australia. Travel Med Infect Dis. 2003;1(1):47-52. http://dx.doi.org/10.1016/S1477-8939(02)00004-2

14. Van Herck K, Castelli F, Zuckerman J, Nothdurft H, Van Damme P, Dahlgren A-L, et al. Knowledge, attitudes and practices in travel-related infectious diseases: the European airport survey. J Travel Med. 2004 Jan-Feb;11(1):3-8. http://dx.doi. org/10.2310/7060.2004.13609

15. Cossar JH, Reid D. Immunisation and health advice for travellers: the role of the general practitioner. Health Bull (Edinb). 1992;50:428-32.

16. Kogelman L, Barnett ED, Chen LH, Quinn E, Yanni E, Wilson ME, et al. Knowledge, attitudes, and practices of US practitioners who provide pre-travel advice. J Travel Med. 2014;21(2):104-14. http://dx.doi.org/10.1111/jtm.12097

17. Al-Abri SS, Abdel-Hady DM, Al Mahrooqi SS, Al-Kindi HS, Al-Jardani AK, Al-Abaidani IS. Epidemiology of travel-associated infections in Oman 1999-2013: A retrospective analysis. Travel Med Infect Dis. 2015 Sep-Oct;13(5):388-93. http://dx.doi.org/10.1016/j. tmaid.2015.08.006

18. Al-Abri SS, Abdel-Hady DM, Al-Abaidani IS; Knowledge, attitudes, and practices regarding travel health among Muscat International Airport travelers in Oman: Identifying the gaps and addressing the challenges. Epidemiol Glob Health. 2016 Mar 3. pii: S2210-6006(15)30123-4. doi: 10.1016/j.jegh.2016.02.003. (Epub ahead of print)

19. Caroll B, Behrens RH, Crichton D. Primary health care needs for travel medicine training in Britain. J Travel Med. 1998;5(1):3-6. http://dx.doi.org/10.1111/j.1708-8305.1998.tboo447.x

20. Leggat PA, Heydon JL, Menon A. Resources used by general practitioners for advising travelers from New Zealand. J Travel Med. 2000;7:55-8.

21. Boddington NL, Simons H, Launders N, Gawthrop M, Stillwell A, Wong C, et al. Evaluation of travel medicine practice by yellow fever vaccination centers in England, Wales, and Northern Ireland. J Travel Med. 2012;19(2):84-91. http://dx.doi.org/10.1111/j.17088305.2011.00587.x

22. Ruis JR, Van Rijckevorsel GGC, van den Hoek A, Koeman SC, Sonder GJB. Does registration of professionals improve the quality of travelers' health advice? J Travel Med. 2009;16(4):263-6. http://dx.doi.org/10.1111/j.1708-8305.2009.00309.x

23. Leggat PA, Heydon JL, Menon A. Training, experience and interest of general practitioners in travel medicine in New Zealand. J Travel Med. 1999;6(2):60-5. http://dx.doi.org/10.1111/j.1708-8305.1999.tboo833.x

24. Keystone JS, Tessier D. A national survey of travel medicine clinics in Canada. J Travel Med. 2003;10(4):247-8. http://dx.doi. $\operatorname{org} / 10.2310 / 7060.2003 .40461$ 